\title{
COMPARISON CRACK RESISTANCE OF RC BEAMS WITH AND WITHOUT TRANSVERSE REINFORCEMENT AFTER SHEAR TESTING
}

doi: 10.2478/cqpi-2019-0046

Date of submission of the article to the Editor: 15/04/2019

Date of acceptance of the article by the Editor: 27/05/2019

Pavlo Vegera ${ }^{1}$ - orcid id: 0000-0002-3437-1825

Roman Khmil'1- orcid id: 0000-0001-7578-8750

Rostyslav Vashkevych ${ }^{1}$ - orcid id: 0000-0001-9962-7580

Zinoviy Blickharskyy ${ }^{1}$ - orcid id: 0000-0002-4823-6405

${ }^{1}$ Lviv Polytechnic National University, Department of Building Constructions and Bridges, Ukraine

\begin{abstract}
Main parameters, which characterize shear strength, are crack distribution, width of diagonal crack opening and angle of inclined crack. There are in this article, comparison crack resistant of testing reinforced concrete $(R C)$ beams on the shear with such variable parameters like presence or absence internal reinforcement, different shear span, and presence or absence external composite reinforcement. Shear span (relative span to effective depth ratio) was acquired the following values: $\mathrm{a} / \mathrm{d}=2,1.5,1$. For internal reinforcement, rebar's $\mathrm{A} 240 \mathrm{C}$ with diameter $8 \mathrm{~mm}$ and steps $100 \mathrm{~mm}$ was chosen. The composite FRCM system was like external reinforcement with three stripe of composite fabric with width $70 \mathrm{~mm}$ and step 100 $\mathrm{mm}$. Eight RC beams were tested. After testing, we discovered that the most influenced on the serviceability capacity was shear span. Internal transverse reinforcing increased shear strength on the same level and it was independent from shear span and other factors. Only quantity of reinforcing determine level of increasing shear capacity. FRCM system is efficient strengthening system, which significant increase shear crack resistant for RC beams. External FRCM reinforcing increase shear crack resistance on the same percentage and independent from presence or absence internal reinforcement.
\end{abstract}

Keywords: RC beam, crack resistant, shear, composite material, FRCM.

\section{INTRODUCTION}

During long-term operation, buildings and constructions were gotten difference type of damages [Selejdak J. et al. 2018.] and defects [Orešković M. et al. 2018]. Main defect is corrosion of internal steel reinforcement, which appear from influence of environmental and other factors [Blikharskyy Z. 2019]. These buildings need reconstruction or strengthening for safety exploitation. At the present stage of technology, composite material is newest modern type of strengthening [David E. et al. 1998]. These materials are made on the basis different types of fibers: carbon, glass, aramid, P.B.O. and others. They have high mechanic characteristic: tensile strength, modulus of elasticity, and low 
self-weight. However, despite this, they are expensive, need high-tech manufacturing, and difficult way to reliable anchoring [Gherdaoui M. and Guenfoud M. 2018].

Traditional method of strengthening, using reinforced concrete jacketing, is needed longterm assembling, significant increasing dimensions and bigger self-weight [Krainskyi P. et al. 2018a.]. Strengthening with CFRP has good adhesion and collaboration between main and adding elements but materials are faster jacketing [Blikharskyy Y. et al. 2018], with values close to strengthening with $\mathrm{RC}$ [Krainskyi P. et al. 2018b.].

Resistance to corrosion, high tensile strength, low weight, easiness and rapidity of application are such characteristics that have contributed to the spread of the strengthening technique characterized by bonding of carbon fibers reinforced polymer (CFRP). [Ferrari V.J. and J.B. De Hanai 2012] research aimed to develop an innovate strengthening method for $\mathrm{RC}$ beams, based on a high performance cement-based composite of steel fibers (macro + microfibers) to be applied as a transition layer.

In the article [Aghayari, R. and Rahimi F. 2018]., deep beams are considered to be important structural components due to their high using in civil engineering, including in tall buildings. The presence of openings in the deep beam will reduce the shear capacity of the beam, so it is important to use the new methods such as the use of resistive shape memory alloys.

Paper [Aljazaeri, Z. R. and Myers J. J. 2017.] presents an experimental study on the behavior of reinforced concrete beams strengthened in shear using an externally applied fiber-reinforced cementitious matrix (FRCM). The test results include the observed shear contribution of the PBO-FRCM system, the failure mode of the strengthened beams, and the influence of the internal transverse shear reinforcements on the shear performance of the PBO-FRCM system.

Experimental and numerical study on a novel structural frame system, which employs $\mathrm{RC}$ encased steel joist beams and columns. Experimental and numerical outcomes have been employed to develop suitable analytical models to be used in practical design. In particular, the beam flexural response has been investigated, providing a simple relationship for the flexural rigidity at different load levels [Amadio C. et al. 2011]. Presents the results of recent tests on diagonal shear failure of reinforced concrete beams without stirrups. The test results indicate a signifycant size effect and show a good agreement with Baiant's lawfor size effect. The tests also show that preventing bond slip of the longitudinal bars (by providing end anchorage with hooks) causes an increase of the brittleness number of the beam [Bazant Z.P and Kazemi M.T. 1991]. In the present study [Chen $\mathrm{H}$. et al. 2018], a novel cracking strut-and-tie model (CSTM) is developed to better predict the shear strength of a deep beam. Rehabilitation of existing structures with carbon fiber reinforced polymers (CFRP) has been growing in popularity because they offer resistance to corrosion and a high stiffness-to-weight ratio. This paper presents the flexural strengthening of seven reinforced concrete $(\mathrm{RC})$ beams with two FRP systems [Ekenel M. et al. 2006].

Very important aspect of different types of strengthening is reliability, because changing stress strain state are changed reliability of whole construction [Khmil, R. 2018].

Current design guidelines neglect shear and shear crack-induced deformations in the calculation of deflections of GFRP RC beams. However, shear-induced deformations can be up to $30 \%$ of the total beam deflection due to the lower stiffness of GFRP bars compared to steel. To calculate the component of deflection due to shear action and crack opening, the proposed model uses a 'single fictitious inclined crack' with a width equal to the sum of the individual effective shear crack widths [Imjai T. et al. 2016]. 
For testing, rectangular reinforced concrete $(\mathrm{RC})$ beams are chosen. RC beams were designed the way that the beams destruction took place by shear, according to [DBN B.2.6-98: 2009], [DSTU B.V.2.6-156: 2010], [EN 1992-1-1:2004]. To accomplish it, these samples were designed with a significant margin of tensile rebar. This is typical for such studies [Alzate A. et al. 2013] [David E. et al. 1998].

For researches, method testing has been developed, which suggested testing each support area separately. It's described in our article [Vegera P. et al. 2015b].

\section{THE TESTING PROGRAM}

Experimental researches allows for testing eight samples. Beams mark follows BO beam ordinary, BSC - beam strengthening by composite materials, the first digit serial number, the second digit - prototypes number and the third digit - the section number. For example, BO 1.2-2 means that the tested example from the first series of the second beam of the second section.

Tested beams were $2100 \mathrm{~mm}$ length, $100 \mathrm{~mm}$ width, and $200 \mathrm{~mm}$ height of cross section. For the 1-st series, as the beam's tension reinforcement, A400C $\varnothing 18 \mathrm{~mm}$ rebar was chosen, A400C $\varnothing 10 \mathrm{~mm}$ - as compressed reinforcement. Constructive transverse reinforcement - A240C $\varnothing 6 \mathrm{~mm}$ rebar located in the area without transverse force [Blikharskyy, Z. et al. 2018.]. For the 2-st series, tension reinforcement, A400C $\varnothing 22 \mathrm{~mm}$ rebar was chosen, A400C $\varnothing 12 \mathrm{~mm}$ - as compressed reinforcement. Transverse reinforcement - A240C $\varnothing 8 \mathrm{~mm}$ rebar, with step $100 \mathrm{~mm}$, located in the supporting area and with step $250-300 \mathrm{~mm}$ in the area without transverse force [Vegera P. et al. 2015a]. Concrete of testing beams is C32/40.

Strengthening system consist from reinforced layer of P.B.O. fabric and mineral cement basement. For strengthening FRCM system are used, as stripes width 70 $\mathrm{mm}$, with step $100 \mathrm{~mm}$ [Vegera P. et al. 2017.] (Fig. 1).

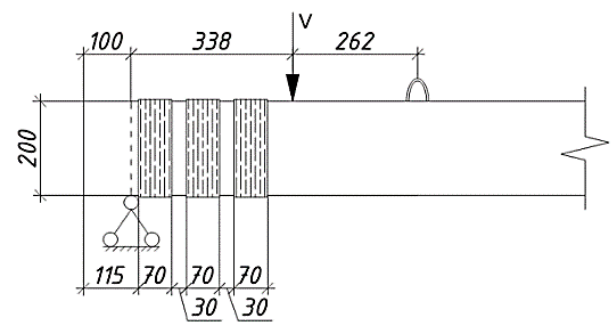

Fig. 1. Scheme of strengthening by FRCM system

Crack's measurements were made using a microscope with accuracy $0.05 \mathrm{~mm}$.

\section{THE OVERVIEW OF TESTING RC BEAMS WITHOUT INTERNAL TRANSVERSE REINFORCEMENT}

At this stage, according to the research program, was tested four samples: three RC beams without strengthening (variable parameter is shear distance $a / d=2 ; a / d=1.5$; $a / d=1$ ) and one beam strengthened by FRCM system (shear distance $a / d=2$ ). Sample was strengthened without initial loading.

Results of the bearing capacity are described in our article [Vegera P. et al. 2018.]. Limit width of the crack $w_{\max }=0.4 \mathrm{~mm}$ reached at the loading level $80 \mathrm{kN}$ for the beam $\mathrm{BO}$ 1.1. Maximum crack opened achieved at the next stage of loading and it was $0.85 \mathrm{~mm}$. 
For beams BO 1.2 (where shear span is $a / d=1.5$ ) characterized opening only one diagonal crack at the angle $40^{\circ}$. This is direction from point of applied loading to the support. For beam BO 1.3 crack expansion was at the angle $45-50^{\circ}$, witch according angle of inclination line from loading point to the beginning of support. Limit value of width of opening cracks was reached at the 100 and $140 \mathrm{kN}$ for beam BO 1.2 and BO 1.3 respectively. It consists $71-76 \%$ from carrying capacity.

External strengthening on the shear averted opening crack. There were increasing number of horizontal and diagonal crack on the surface in the support area opened. Maximum width of these cracks were 0.05-0.2 mm. Main (destructive) crack was opened at the angle $30-35^{\circ}$. Width of crack opening was $0.4 \mathrm{~mm}$ on the concrete surface, and it was fixed before beam exhausted caring capacity.

On the surface of the FRCM system, we fixed many small horizontal crack with opening 0.1-0.2 mm. Whereas beam was strengthened with shear span $a / d=2$, second diagonal crack opened, at the angle $34^{\circ}$.

Strengthening beam showed higher crack resistance: limit width of crack opening was at $80 \%$ of carrying capacity. Maximum width of crack opening was $0.5-0.6 \mathrm{~mm}$ at last stage of loading.

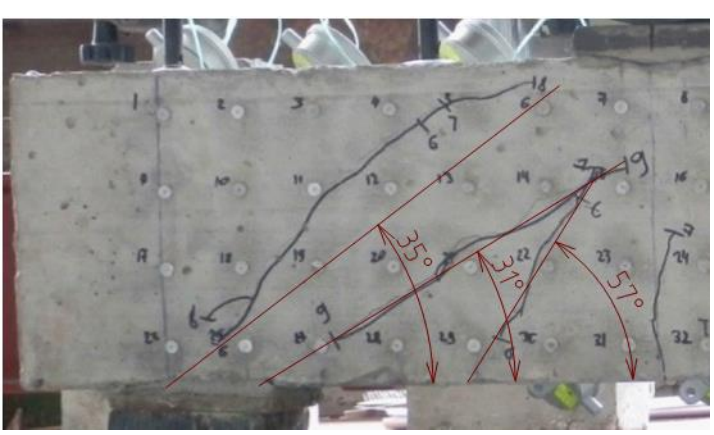

a)

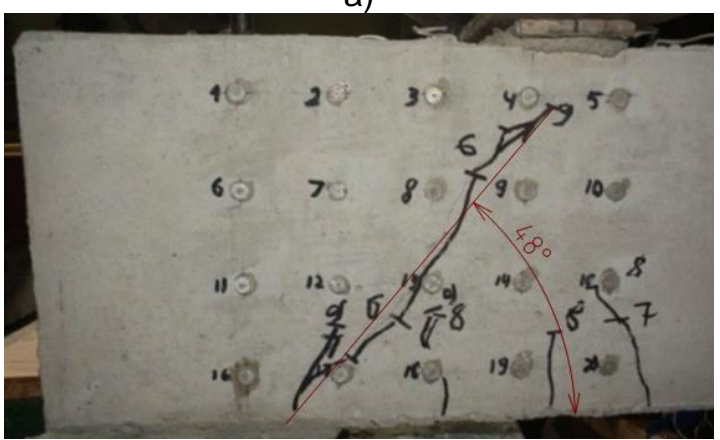

c)

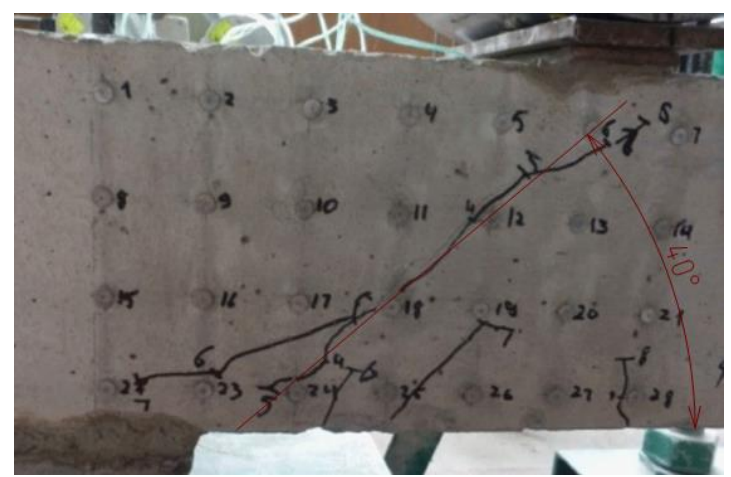

b)

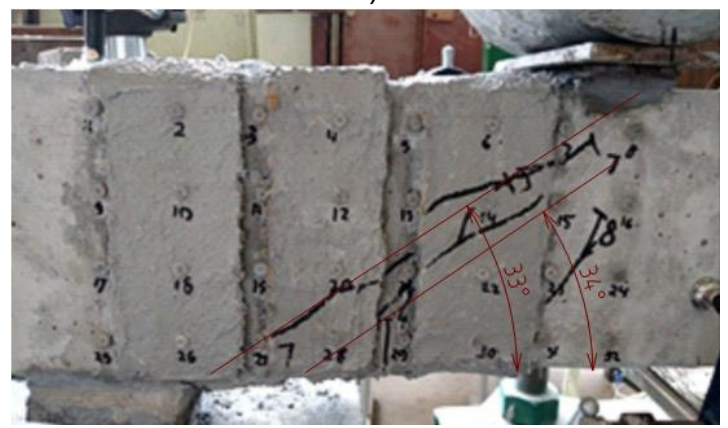

d)

Fig 2. Scheme of opening and distribution shear crack in the beam: a)BO1.1; b) BO 1.2; c) BO 1.3; d) BSC 1.4

\section{THE OVERVIEW OF TESTING RC BEAMS WITH INTERNAL TRANSVERSE REINFORCEMENT}

Four samples from second series was tested with the same changing parameters. In these samples, general principles of distribution shear cracks are different from similar samples of first series.

First two $\mathrm{RC}$ beam had the same angle of opening, which is in range from $30^{\circ}$ to $41^{\circ}$.

Limit value of width of opening cracks was reached at the 120 and $140 \mathrm{kN}$ for beam BO 2.1 and BO 2.2 respectively. It is consisting 76-81\% from carrying capacity. The last beam $\mathrm{BO} 2.3$, which tested with shear span $\mathrm{a} / \mathrm{d}=1$, was had only one inclined crack. It 
was destructive one. Angle of distribution was $46^{\circ}$, which responded direction from point of applying loading to the center of support. It is close to value of angle of inclination of cracks in the first two beam (BO 2.1 and BO 2.2). For this beam, limit value of the crack opening was reached at the load $190 \mathrm{kN}$. This is $74 \%$ from beams carrying capacity.

Maximum values of cracks opening were measurement on the last stage before expect exhaustion of carrying capacity. It should be noted that was fixed significant increase width of crack opening at the last stage of loading (after fixed limit value of width of crack opening). The value of growth could be up to two times higher. For sample BO 2.1, maximum width of crack opening was $0.75 \mathrm{~mm}$, for BO $2.2-0.7$. In addition, for beam BO 2.3 it was smaller, only $0.45 \mathrm{~mm}$.

Beam BSC 2.4, with external FRCM reinforcement, had crack distribution the same type as for BSC 1.4. Angle of inclined crack is only one significant difference between these samples. Internal reinforcement makes better spread of inclined crack with sharper angle $\left(33^{\circ}\right.$ in the BSC 1.4 against $27^{\circ}$ in the BSC 2.4). External reinforced increased loading level when opened crack with limit value. It was $150 \mathrm{kN}$ and it is $81 \%$ from carrying capacity of the beam. Maximum crack opening was $0.4 \mathrm{~mm}$ on the concrete surface and 0.2-0.3 $\mathrm{mm}$ on the surface of the strengthening.

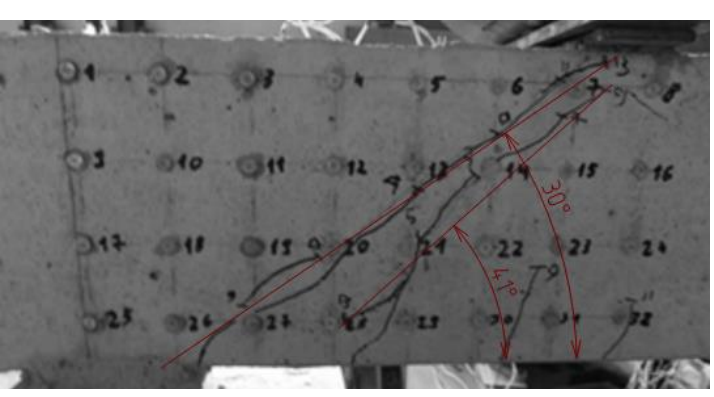

a)

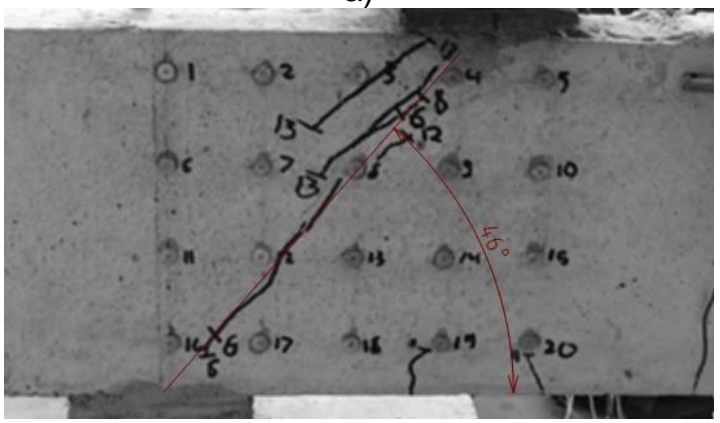

c)

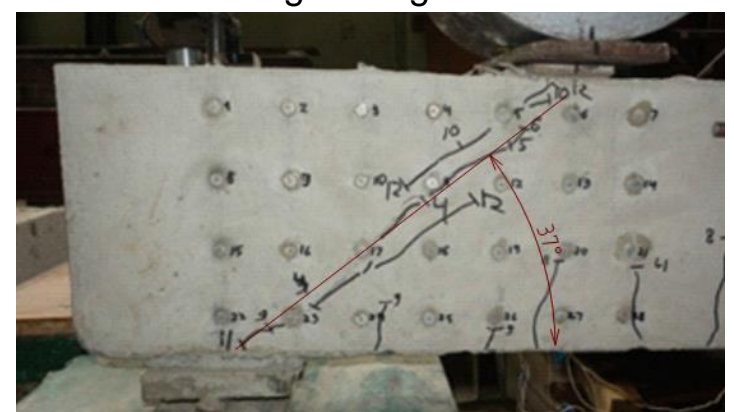

b)

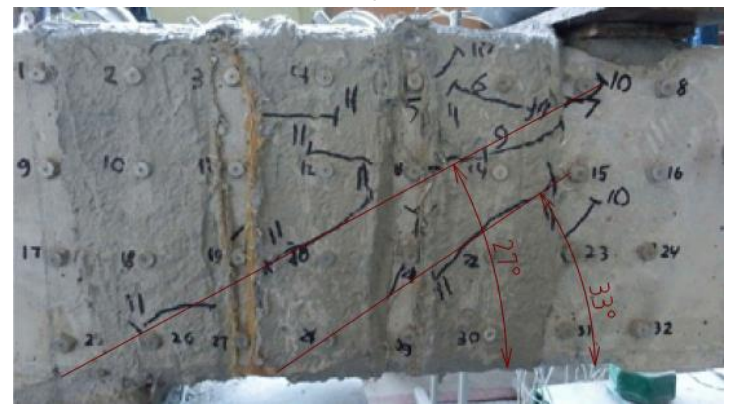

d)

Fig 3. Scheme of opening and distribution shear crack in the beam: a)BO2.1; b) $\mathrm{BO} 2.2$;

c) BO 2.3; d) BSC 2.4

\section{ANALYZE OF THE EXPERIMENTAL RESULTS}

Tested beams of the 1 -st series is show increasing serviceability capacity, when limit value of width of inclined crack opening was applied.

With decreasing shear span was fixed increasing capacity from 80 to $150 \mathrm{kN}$. Along with this maximum crack opening decreasing from 0.85 to $0.55 \mathrm{~mm}$. Using the limit crack opening width as criteria of exhaustion capacity we saw that used about $71-84 \%$ of carrying capacity of the beam. In addition, angle of the inclined (destructive) crack was changing with changed shear span. With higher angle fixed of decreased maximum crack opening and more rapidly characters of destruction of $\mathrm{RC}$ beams [Vegera P. et al. 2015]. 
Strengthening beam was show more slowly growth of the width of inclined crack opening. Maximum value was fixed $0.5 \mathrm{~mm}$. However, serviceability capacity is higher (amount $110 \mathrm{kN}$ ) we can conclude that the system efficiently increases capacity of the beam. All other results for sample BSC 1.4 are close by value for the sample with the same shear span (sample BO 1.1).

Strengthening sample had somewhat higher capacity than beam BO 1.2 but showed the lowest level of maximum width of crack opening and usage the carrying capacity is consist of $80 \%$ witch are high results and close by value for unstrengthening sample.

Similar distribution of the parameters is fixed for samples of the 2-nd series (with internal steel reinforcement).

For samples BO 2.1 and BSC 2.4, which have similar shear distance $a / d=2$, was the same level of loading from carrying capacity, when cracks opening width was $0.4 \mathrm{~mm}$. In this case, strengthening increased serviceability capacity proportional. The boundary values of the crack opening width are fixed at $74-81 \%$ of the load carrying capacity of the samples. External strengthening system reduced maximum crack opening about 1.75 times: from 0.75 to $0.43 \mathrm{~mm}$ and values exceed limit insignificant. Therefore, FRCM system is a good method of enhancement crack resistant.

Comparison parameters of crack resistant the same samples from different series are described in the table 1.

Table 1

Comparison of crack resistant of the tested samples

\begin{tabular}{|c|c|c|c|c|c|c|c|c|}
\hline \multirow{2}{*}{$\begin{array}{c}\text { Parameters of shear } \\
\text { crack resistant }\end{array}$} & \multicolumn{2}{|c|}{$\begin{array}{c}\text { Shear span } \\
\mathbf{a} / \mathbf{d}=\mathbf{2}\end{array}$} & \multicolumn{2}{c|}{$\begin{array}{c}\text { Shear span } \\
\mathbf{a} / \mathbf{d}=\mathbf{1 / 5}\end{array}$} & \multicolumn{2}{c|}{$\begin{array}{c}\text { Shear span } \\
\mathbf{a} / \mathbf{d}=\mathbf{1}\end{array}$} & \multicolumn{2}{c|}{$\begin{array}{c}\text { Shear span } \\
\mathbf{a} / \mathbf{d}=\mathbf{2} \text { with } \\
\mathbf{F R C M}\end{array}$} \\
\cline { 2 - 11 } & $\begin{array}{c}\text { BO } \\
\mathbf{1 . 1}\end{array}$ & $\begin{array}{c}\text { BO } \\
\mathbf{2 . 1}\end{array}$ & $\begin{array}{c}\text { BO } \\
\mathbf{1 . 2}\end{array}$ & $\begin{array}{c}\text { BO } \\
\mathbf{2 . 2}\end{array}$ & $\begin{array}{c}\text { BO } \\
\mathbf{1 . 3}\end{array}$ & $\begin{array}{c}\text { BO } \\
\mathbf{2 . 3}\end{array}$ & $\begin{array}{c}\text { BSC } \\
\mathbf{1 . 4}\end{array}$ & $\begin{array}{c}\text { BSC } \\
\mathbf{2 . 4}\end{array}$ \\
\hline $\begin{array}{c}\text { Level of loading, when width } \\
\text { of crack opening was 0.4 } \\
\text { mm., kN }\end{array}$ & 80 & 120 & 100 & 140 & 150 & 190 & 110 & 150 \\
\hline $\begin{array}{c}\text { Loading level from carrying } \\
\text { capacity of the beam, \% }\end{array}$ & 84 & 81 & 71 & 77 & 76 & 74 & 80 & 81 \\
\hline $\begin{array}{c}\text { Maximum inclined crack } \\
\text { width, mm }\end{array}$ & 0.85 & 0.75 & 0.65 & 0.7 & 0.55 & 0.45 & 0.5 & 0.4 \\
\hline Angle of inclined crack & $31^{\circ}$ & $30^{\circ}$ & $40^{\circ}$ & $37^{\circ}$ & $48^{\circ}$ & $46^{\circ}$ & $33^{\circ}$ & $27^{\circ}$ \\
\hline
\end{tabular}

Analyzing the presented data can be concluded that internal reinforcement increased serviceability capacity for all beam at the almost the same level and increasing don't de-pend from shear span. External reinforcement showed the same relationship: serviceability capacity increasing on the $30 \mathrm{kN}$ and independent from presence or absence internal reinforcement

In all beams 2-nd series decreased maximum width of the cracks opening. Strengthening system decreased width of inclined crack opening by half.

For samples with the same shear span, loading level, when limit value of width of inclined crack opening is achieved, is the same before the danger of shear failure of the beam. It should be noted that angle of inclined crack doesn't depend from internal or external reinforcement, but only from shear span. Value of the angle is close by size between samples of different series (divergence less than 7\%). Only for strengthened samples is more divergence (somewhere 19\%). This is important for 
determining angle of the compressed inclined concrete elements in the "truss model" calculation of shear strength. [EN 1992-1-1:2004; DSTU B.V.2.6-156: 2010].

\section{SUMMARY AND CONCLUSION}

Based on the data above, the following conclusions can be made:

- the shear span is main parameter, which most influenced on the serviceability capacity;

- for samples with or without internal reinforcement, parameters of the crack resistance changed for the same relationships;

- for all experimental samples, exhausting serviceability capacity was fixed at the loading level $71-84 \%$ from their shear capacity;

- when shear span decrease the maximum serviceability capacity increase but percentage from shear capacity decrease;

- Internal transverse reinforcing increased shear strength on the same level and it was independent from shear span and other factors. Only quantity of reinforcing determines level of increasing shear capacity.

- $\quad$ FRCM system is efficient strengthening system, which significantly increase crack resistance on the shear for $\mathrm{RC}$ beams;

- external FRCM reinforcing increase shear crack resistance on the same percentage and independent from presence or absence internal reinforcement.

\section{REFERENCES}

Aghayari R., \& Rahimi F. 2018 The Novel Method for Rising up the Shear Strength and Limiting the Growth of Cracks in Deep Beams with SMA. International Conference on New Horizons in the Engineering Science ISTANBUL - TURKEY

Aljazaeri Z. R., \& Myers J. J. 2017. Strengthening of Reinforced-Concrete Beams in Shear with a Fabric-Reinforced Cementitious Matrix. Journal of Composites for Construction, 21(5), 1-8.

Alzate A., Arteaga A., Diego de A., Cisneros D., Perera R. 2013. Shear strengthening of reinforced concrete members with CFRP sheets. Materiales de Construcción. 63(310), 251-265.

Amadio C., Macorini L, Sorgon S., Suraci G. 2011. A novel hybrid system with RCencased steel joints. EJECE. 15(10), 1433-1463.

Bazant Z.P, Kazemi M.T. 1991. Size effect on diagonal shear failure of beams without stirrups. ACI Structural journal. 88 (3), 268-276.

Blikharskyy Y., Khmil R., \& Blikharskyy Z. 2018. Research of RC columns strengthened by carbon FRP under loading. MATEC Web of Conferences. 174.

Blikharskyy Z., Selejdak J., Blikharskyy Y., \& Khmil R. 2019. Corrosion of Reinforce Bars in RC Constructions. System Safety: Human - Technical Facility Environment. 1. 277-283. 10.2478/czoto-2019-0036.

Blikharskyy, Z., Vegera, P., Vashkevych, R., Shnal, T. 2018. Fracture toughness of $R C$ beams on the shear, strengthening by FRCM system. MATEC Web of Conferences. 183. 02009.

Chen H., Yi W. J., \& Hwang, H. J. 2018. Cracking strut-and-tie model for shear strength evaluation of reinforced concrete deep beams. Engineering Structures, 163, 396-408.

David E. Djelal C., Buyle-Bodin F. 1998. Repair and strengthening of reinforced concrete beams using composite materials. 2nd international PhD Symposium in civil engineering, Budapest, 23-34.. 
DBN B.2.6-98: 2009 Concrete and reinforced concrete construction. Kyiv, Minbudrehion Ukraine, 2011.

DSTU B.V.2.6-156: 2010 Concrete and reinforced concrete construc-tion with heavy concrete. Kyiv, Minbudrehion Ukraine, 2011.

Ekenel M., Rizzo A., Myers J.J., Nanni A. 2006. Flexural fatigue behaviour of reinforced concrete beams strengthened with FRP fabric and procured laminate systems. Journal of composites for construction. 1, 433-442.

EN 1992-1-1:2004 (E) Eurocode 2: Design of concrete structures - Part 1-1: General rules for buildings. Brussels, GEN, 2004.

Ferrari V.J. J.B. De Hanai. 2012. Flexural strengthening of rein-forced concrete beams with carbon fibres reinforced polymer (CFRP) sheet bonded to a transition layer of high performance cement-based composite. Ibracon structural and materials journal. 5 (5), 596-626.

Gherdaoui M., \& Guenfoud M. 2018. Repairing reinforced concrete slabs by composite materials. J. Mater. Environ. Sci, 9 (2). 701-708.

Imjai T., Guadagnini M., Garcia R., \& Pilakoutas K. 2016. A practical method for determining shear crack induced de-formation in FRP RC beams. Engineering Structures. 126, 353-364.

Khmil, R., Tytarenko R., Blikharskyy, Y., Vegera, P. (2018). Development of the procedure for the estimation of reliability of reinforced concrete beams, strengthened by building up the stretched reinforcing bars under load. EasternEuropean Journal of Enterprise Technologies, 5/7(95), 32-42.

Krainskyi P., Blikharskyy Y., Khmil R., Blikharskyy Z. 2018. Experimental study of the strengthening effect of reinforced concrete columns jacketed under service load level. MATEC Web of Conferences. 183. DOI: 10.1051/matecconf/201818302008

Krainskyi P., Blikharskyy Y., Khmil R., Vegera P. 2018. Influence of loading level on the bearing capacity of $R C$ columns strengthened by jacketing. MATEC Web of Conferences. 230. DOI: 10.1051/matecconf/201823002013.

Orešković M., Klymenko I., Aniskin A., \& Kozina G. 2018. Analysis of Damaged Concrete Columns of Circular Cross-Section. Tehnički vjesnik, 25(2), 337-343. DOI 10.17559/TV-20160621085905.

Selejdak J., Khmil R., Blikharskyy Z. 2018. The influence of simultaneous action of the aggressive environment and loading on strength of $R C$ beams. MATEC Web of Conferences. 183. DOI: 10.1051/matecconf/201818302002

Vegera P. Khmil R., \& Blikharskyy Z. 2017. Shear strength of reinforced concrete beams strengthened by P.B.O. fiber mesh under loading. MATEC Web of Conferences Volume 116. DOI: 10.1051/matecconf/201711602006.

Vegera P., Khmil R., \& Blikharskyy Z. 2015. Optimization of the methodology of experimental research of inclined sections of reinforced concrete beams. Theory and Building Practice. 823. 38-43. (In Ukrainian)

Vegera P., Khmil R., \& Blikharskyy Z. 2015. The shear capacity of reinforced concrete beams with different shear span to effective depth ratio. Zeszyty Naukowe Politechniki Często-chowskiej. Budownictwo. 21 (171). 355-364.

Vegera P., Vashkevych R., \& Blikharskyy Z. 2018. Fracture toughness of RC beams with different shear span. MATEC Web of Conferences. 174. DOI: 10.1051/matecconf/201817402021. 